\title{
Genetic relationships between 14 native Spanish breeds of goat
}

\author{
M. J. TUÑÓN, P. GONZALEZ \& M. VALLEJO*
}

Biología, Facultad de Veterinaria, León, Spain and * Genética y Mejora, Facultad de Veterinaria, Madrid, Spain

Summary. The genetic distances separating 14 Spanish goat breeds are calculated from gene frequency data of 14 genetic blood markers $(\mathrm{GSH}, \mathrm{Ke}, \mathrm{Hb}, \mathrm{Dia}, \mathrm{Ct}$, $\mathrm{MDH}, \mathrm{CA}, \mathrm{X}, \mathrm{NP}, \mathrm{Alp}, \mathrm{Am}, \mathrm{Cp}$, Tf and Al).

Working from the matrix of Nei's genetic distances we drew a dendrogram demonstrating a great genetic similarity among populations from Negra Serrana, Zamorana, Guadarrama, Retinta, Blanca Andaluza, Berciana and Pirenaica on one hand; and Canaria, Murciana, Blanca Celtibérica, Verata, Palmera, Malagueña and Granadina on the other.

We discuss the similarities and differences within our classification using gene frequency data of the blood genetic markers studied, and classifications based chiefly on morphological and production data.

Keywords: Spanish goats, biochemical polymorphism, genetic relationship

\section{Introduction}

There are many ways of expressing the genetic distance between populations but despite the controversies which have arisen over the best genetic distance, many authors have shown that comparison of different methods generally leads to very similar results (Gregorius 1974; Chakraborty \& Tateno 1976; Aupetit 1985). For the present study we used the genetic distance model suggested by Nei (1972).

Much research has been carried out worldwide into blood biochemical polymorphisms in order to study the genetic relationships between populations of various species of farm animals, especially cattle and sheep (Kidd 1974; Abe et al. 1977; Ordás \& San Primitivo 1986). However, very little work has been done with goats, the only Spanish breeds previously studied being Granadina, Murciana, Malagueña and Blanca Andaluza (Barbancho 1980) while the only foreign breeds studied are a few Asiatic ones (Nozawa et al. 1978; Katsumata et al. 1981a,b, 1982).

This paper constitutes the first attempt at a systematic and complete analysis of the phylogenetic relationships existing between Spanish native goat breeds with the help of biochemical markers.

Correspondence: Dra M.J. Tuñón, Biología, Facultad de Veterinaria, Universidad de León, Campus de la Vegazana, 24007 León, Spain.

Accepted 20 January 1988 


\section{Materials and methods}

We analysed a total of 1370 blood samples taken at random from 14 native Spanish breeds: 115 Pirenaica and 100 Berciana from León, 100 Verata and 108 Retinta from Cáceres, 101 Guadarrama from Madrid, 110 Zamorana from Zamora, 101 Granadina from Granada, 100 Blanca Andaluza from Huelva, 100 Murciana from Murcia, 100 Blanca Celtibérica from Guadalajara, 100 Negra Serrana from Ciudad Real, 100 Malagueña from Málaga, 99 Canaria and 36 Palmera from Canary Island.

The description of the breeds is derived from Esteban \& Tejón (1983).

Pirenaica. This is a medium-sized animal with subconcave profile and scimitarshaped horns. The background colour of its coat is reddish grey with variable black markings. It is farmed for milk and meat production in pasture with flocks of $100-300$ head.

Verata. This is a medium- or small-sized animal with subconcave profile and twisted horns. It is black, livid or brown. It is a good milk and meat producer.

Guadarrama. This is a medium-sized animal with subconcave profile and scimitar-shaped horns. The coat colour is black. It is an acceptable meat and milk producer.

Zamorana. This is a medium- or small-sized animal with subconcave profile and twisted horns. The coat colour is brilliant black. It is farmed for meat and milk production in pasture with flocks of 100-400 head.

Berciana. This is a medium- or small-sized animal with subconcave profile and generally scimitar-shaped horns. The coat colour is blonde. It is a good meat producer.

Murciana and Granadina. These are medium-sized animals with subconcave profile. These goats are polled, and when horns are present they are scimitar-shaped. The coat colour is black (Granadina) and reddish-brown (Murciana). These two breeds are very good milk producers.

Blanca Andaluza. This is a large-sized animal with convex profile, elongate proportions and twisted horns. The coat colour is white. This is a good meat producer.

Blanca Celtibérica. This is a medium-sized animal with straight profile and twisted horns. It is white. It is a milk and meat producer.

Negra Serrana. This is a large-sized animal with convex profile, elongate proportions and twisted horns. The coat colour of this breed is usually black, sometimes with a few white patches. It is only a meat producer.

Malagueña. This is a medium-sized animal with straight or slightly subconvex profile and elongate proportions. These goats are polled, and when horns are present they are scimitar-shaped. The coat colour is blonde or white. It is a very good milk producer.

Canaria. These are medium- or large-sized animals with convex, straight or concave profile and generally scimitar-shaped horns although there are polled animals. The coat colour is variable. They are very good milk producers.

Palmera. This is a medium-sized animal with subconcave profile and twisted horns. The coat colour is generally reddish. It is a very good milk producer. 
Retinta. This is a medium-sized animal with straight profile and scimitar-shaped horns. It is dark chestnut. It is a meat and milk producer.

Fourteen blood genetic systems were analysed, comprising nine erythrocyte systems: reduced glutathione $(\mathrm{GSH})$, red cell potassium $(\mathrm{Ke})$, haemoglobin $(\mathrm{Hb})$, diaphorase (Dia), catalase $(\mathrm{Ct})$, malate dehydrogenase $(\mathrm{MDH})$, carbonic anhydrase (CA), X-protein (X), nucleoside phosphorylase (NP); and 5 plasmatic ones: alkaline phosphatase (Alp), amylase (Am), ceruloplasmin $(\mathrm{Cp})$, transferrin (Tf) and albumin (Al).

GSH levels in erythrocytes were determined spectrophotometrically using the method described by Beutler et al. (1963). The $\mathrm{K}^{+}$levels in whole blood and plasma were determined by flame photometry. The concentration of potassium in the erythrocytes was calculated according to Evans' formula (1954).

The remaining genetic systems, both of red cells and of serum, were analysed by horizontal electrophoresis on starch gel using the following methods: Hb (Braend 1963), Dia, Ct and MDH (Valenta et al. 1967), CA, X and NP (Tucker et al. 1967), Alp (Rendel \& Stormont 1964), Am (Trowbridge \& Hines 1979), Cp (Kristjansson 1963) and Tf and Al (Efremov \& Braend 1965).

The genetic relationships between the 14 goat breeds were studied by means of Nei's genetic distance (D) method (Nei 1972), from a matrix of which a dendrogram was drawn according to the method proposed by Sneath \& Sokal (1973).

\section{Results}

Of the 14 genetic systems studied, six (GSH, Ct, MDH, CA, NP and Cp) turned out to be monomorphic in all the goat populations studied.

Table 1 shows the gene frequencies for the 14 genetic systems analysed for the 14 Spanish breeds of goat. The data allowed us to establish the degree of similarity or difference between the 14 populations by means of two different genetic-statistical methods: genetic distances and dendrograms.

Table 2 shows the matrix of Nei's genetic distances. D values ranged from 0.003 (Granadina-Malagueña) to 0.097 (Murciana-Retinta). Distance values of only 0.004 were given by the pairs Pirenaica-Berciana, Zamorana-Negra Serrana, Berciana-Blanca Andaluza and Blanca Andaluza-Negra Serrana.

The dendrogram (Fig. 1) shows two clearly different groups of populations: one, Negra Serrana, Zamorana, Guadarrama, Retinta, Blanca Andaluza, Berciana and Pirenaica; and two, Canaria, Murciana, Blanca Celtibérica, Verata, Palmera, Malagueña and Granadina.

\section{Discussion}

From the genetic distance values obtained we infer that the majority of the most homogeneous populations are those considered to belong to the fully extensive system and kept mainly for meat production. 


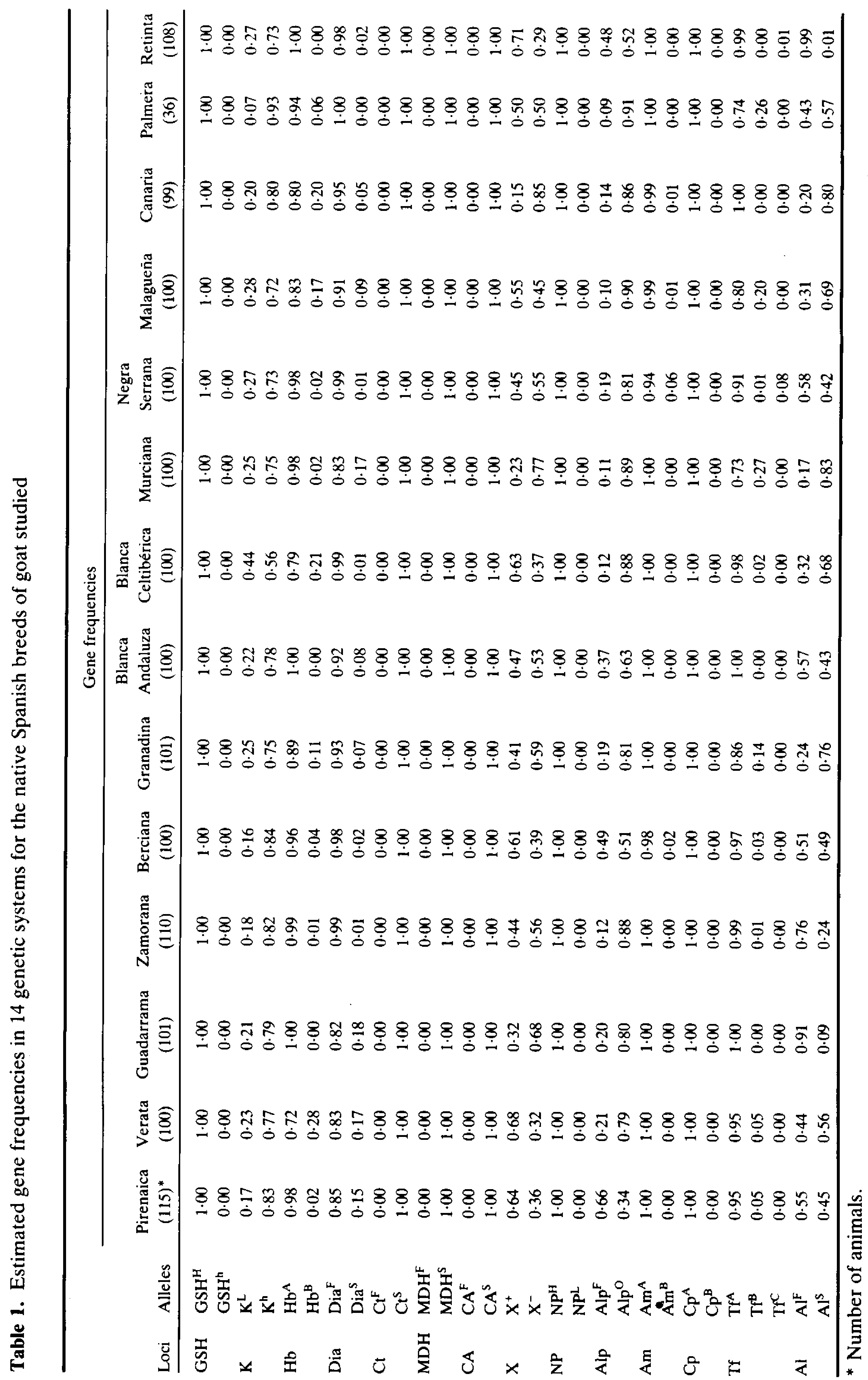




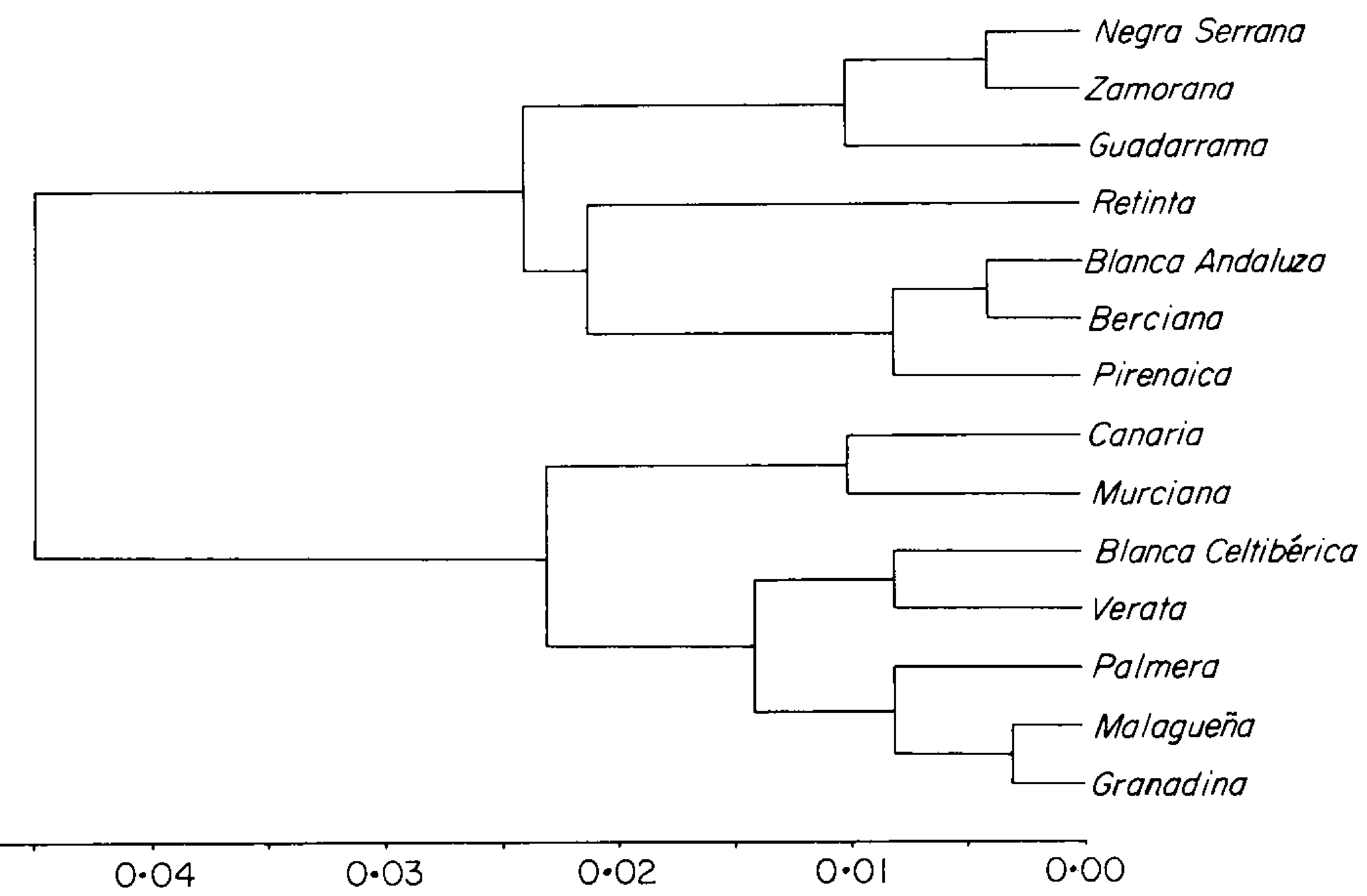

Figure 1. Dendrogram showing the genetic affinity of goat populations.

Few studies of genetic distances have been undertaken for breeds of goat. The only foreign ones studied are Asiatic ones: in eight populations in Okinawa (Japan), the distances found were from 0.0004 to 0.0025 (Nozawa et al. 1978); higher values were found in seven native Indonesian populations, ranging from 0.0011 to 0.0174 (Katsumata et al. 1981a); seven populations of Japanese Saanen gave results between 0.0004 and 0.0065 (Katsumata et al. 1981b); and finally, values of 0.0001 to 0.0056 were found in six native populations in Korea (Katsumata et al. 1982). We should nevertheless point out that the object of all these studies was to establish genetic divergences within breeds, which means that the $\mathrm{D}$ values obtained were in most cases clearly lower than our results between various Spanish native breeds.

Regarding Spanish goats, Barbancho (1980) observed while studying genetic distances separating the Murciana, Granadina, Malagueña and Blanca Andaluza breeds, that the greatest differences were between the last mentioned and any of the other three, while the most closely related were Murciana and Granadina. Our results (Table 2) bear out the position concerning Blanca Andaluza, while the distances between the remaining three are short, as is normal among breeds considered from their morphological and production characteristics to be closely related.

Traditional Spanish ethnology (Aparicio 1960) gives three prehistoric branches for the origin of the Spanish goat breeds.

One, originating from Capra aegagrus, would have given rise to the Pirenaica, Murciana, Granadina, Malagueña and 'de las Mesetas' breeds, this last term covering Verata, Zamorana and Berciana breeds. A second branch originating in the extinct Capra prisca represented only by Blanca Celtibérica. A third branch of 
$210 M . J$. Tuñón et al.

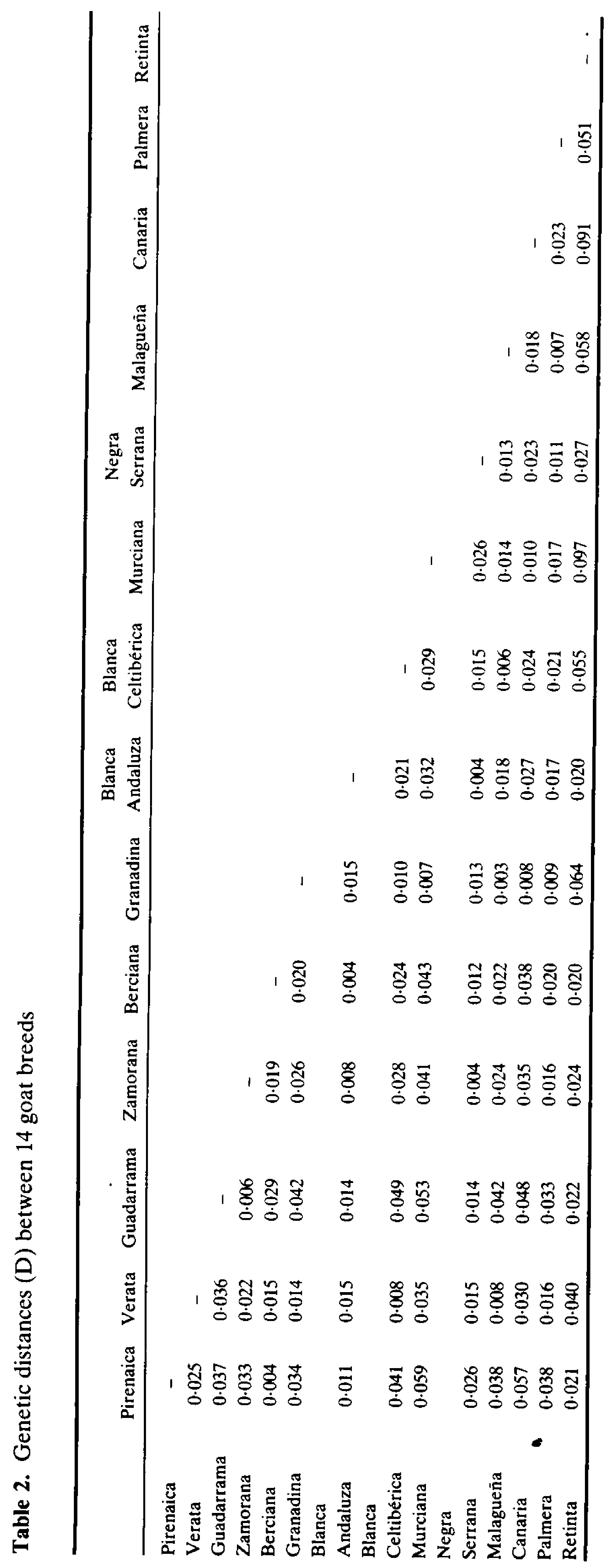


unknown origin gave rise to the modern Blanca Andaluza. However, Aparicio (1960) himself states that the formation of the modern breeds would have implied several crossings between the primitive forms.

It should also be borne in mind that there is no general agreement on criteria concerning the origin of the domestic goat, Bökönyi (1974), working from conclusive data offered by various authors, considers that $C$. aegagrus alone may be considered the wild ancestor of domestic goats, at least of the European ones.

However, it must be realized that the dendrograms thus obtained do not offer any information concerning time, or data on the common ancestor. In this regard Nei (1975) emphasizes that the dendrogram only represents genetic relationships between breeds, but may or may not show the true evolutionary history of populations, especially when these are not completely isolated.

We consider that any classification of breeds should take into account not only the genetic aspect, but also, among others, the ethnological, ecological and etological aspects. In this regard, one is easily convinced that consideration of ecological and production characteristics gives greater sense to the division of the Spanish goat breeds studied into two groups, as the top branch of the dendrogram includes populations generally sites in the north and centre of Spain, in a fully extensive regime of exploitation, while the bottom branch comprises breeds from hotter areas, corresponding to either semi-intensive exploitation or intensive dairy farming.

For the reasons mentioned, we consider that the great subdivisions to be observed on our dendrogram (Fig. 1) should not be interpreted as two independent evolutionary branches, but rather as two groups that have become genetically differentiated from $C$. aegagrus, according to factors of habitat, means of exploitation and production capacity.

We feel, therefore, that the data obtained from studies of blood genetic systems should be combined with other data, such as osteometric ones, as the phylogenetic relationships of the Spanish goat breeds are still far from being resolved.

\section{References}

Abe T., Oishi T. \& Komatsu M. (1977) Genetical constitution of Japanese cattle breeds as determined by the gene frequencies of blood groups and protein types. Bulletin of the National Institute of Animal Industry 32, 63-9.

Aparicio G. (1960) Etnología compendiada. Imprenta Moderna, Córdoba.

Aupetit R.Y. (1985) Analyse des relations phylogénétiques entre les races bovines françaises par le polymorphisme biochimique. These docteur des Ciences Naturelles, Université de Paris.

Barbancho M. (1980) Estructura y relaciones genéticas entre algunas razas caprinas españolas en razón a determinados polimorfismos sanguíneos. Tesis doctoral, Universidad de Córdoba.

Beutler E., Duron O. \& Kelly B.M. (1963) Improved method for the determination of blood glutathione. Journal of Laboratory and Clinical Medicine 61, 882-8.

Bökönyi S. (1974) History of Domestic Mammals in Central and Eastern Europe. Akadémiai Kiadó, Budapest.

Braend M. (1963) Haemoglobin and transferrin types in the American buffale. Nature 197, 910.

Chakraborty R. \& Tateno Y. (1976) Correlations between some measures of genetic distance. Evolution 30, 851-3. 
Efremov G. \& Braend M. (1965) Haemoglobins, transferrins and albumins of sheep and goats. Proceedings of the 9th European Conference on Animal Blood Groups and Biochemical Polymorphisms, Prague, 1964, pp. 313-20.

Esteban C. \& Tejón D. (1983) Catálogo de razas autóctonas españolas. I. Especies ovina y caprina. Publicaciones de Extensión Agraria, Ministerio de Agricultura, Madrid.

Evans J.V. (1954) Electrolyte concentrations in red blood cells of British breeds of sheep. Nature 174, 931-2.

Gregorius H.R. (1974) On the concept of genetic distance between populations based on gene frequencies. Proceedings of the Joint IUFRO Meeting, S. 02, 04-1-3, Stockholm, pp. 17-26.

Katsumata M., Amano T., Suzuki S., Nozawa K., Martojo H., Abdulgani I.K. \& Nadjib H. (1981a) Morphological characters and blood protein gene constitution of Indonesian goats. In: The Origin and Phylogeny of Indonesian Native Livestock. Part II (Report by Grant -- in Aid of Overseas Scientific Survey, 504353), pp. 55-68.

Katsumata M., Amano T., Tanaka K., Nozawa K., Bahk K.S., Park B.J. \& Lee C.H. (1982) Blood protein variations of the Korean native goats. Japanese Journal of Zootechnical Science 53, 521-7.

Katsumata M., Nozawa K., Amano T., Shinjo A. \& Abe T. (1981b) Blood protein gene constitution of the Japanese Saanen breed of goat. Japanese Journal of Zootechnical Science 52, 553-61.

Kidd K.K. (1974) Biochemical polymorphism, breed relationships, and germ plasm resources in domestic cattle. 1st World Congress on Genetics Applied to Livestock Production, Madrid 1, 321-7.

Kristjansson F.K. (1963) Genetic control of two prealbumins in pigs. Genetics 48, 1059-63.

Nei M. (1972) Genetic distance between populations. American Naturalist 106, 283-92.

Nei M. (1975) Molecular Population Genetics and Evolution, pp. 198-201. North Holland, Amsterdam.

Nozawa K., Shinjo A. \& Shotake T. (1978) Population genetics of farm animals. III. Blood protein variations in the meat goats in Okinawa Islands of Japan. Zeitschrift für Tierzüchtung und Züchtungsbiologie 95, 60-77.

Ordás J.G. \& San Primitivo F. (1986) Genetic variations in blood proteins within and between Spanish dairy sheep breeds. Animal Genetics 17, 255-66.

Rendel J. \& Stormont C. (1964) Variants of ovine alkaline serum phosphatases and their association with the R.O blood groups. Proceedings of the Society for Experimental Biology and Medicine 115, 853-6.

Sneath P.H.A. \& Sokal R.R. (1973) Numerical Taxonomy, pp. 230-4. Freeman, San Francisco.

Trowbridge C.L. \& Hines H.C. (1979) Amylase genetic variation of serum in Holstein cattle. Journal of Dairy Science 62, 982-4.

Tucker E.M., Suzuki Y. \& Stormont C. (1967) Three new phenotypic systems in the blood of sheep. Vox Sanguinis 13, 246-62.

Valenta M.J., Hyldgaard-Jensen J. \& Moustgaard J. (1967) Three lactic dehydrogenase isoenzyme systems in pig spermatozoa and the polymorphism of sub-units controlled by third locus C. Nature 216, 506-7. 